Article

\title{
Exploring the Channels of Transmission between External Debt and Economic Growth: Evidence from Sub-Saharan African Countries
}

\author{
Adewale Hassan ${ }^{1}(1)$ and Daniel Meyer ${ }^{2, *}$ \\ 1 Faculty of Economic and Management Sciences, TRADE Research Entity, North West University, \\ Potchefstroom 2520, South Africa; adewale706@gmail.com \\ 2 College of Business and Economics, Department of Public Management and Governance, \\ University of Johannesburg, Johannesburg 2001, South Africa \\ * Correspondence: dfmeyer@uj.ac.za
}

check for updates

Citation: Hassan, Adewale, and Daniel Meyer. 2021. Exploring the Channels of Transmission between External Debt and Economic Growth: Evidence from Sub-Saharan African Countries. Economies 9: 50. https:// doi.org/10.3390/economies9020050

Received: 15 January 2021

Accepted: 1 March 2021

Published: 6 April 2021

Publisher's Note: MDPI stays neutral with regard to jurisdictional claims in published maps and institutional affiliations.

Copyright: (c) 2021 by the authors. Licensee MDPI, Basel, Switzerland. This article is an open access article distributed under the terms and conditions of the Creative Commons Attribution (CC BY) license (https:// creativecommons.org/licenses/by/ $4.0 /)$

\begin{abstract}
This study aimed to determine the channels through which external debt transmits its impact on economic growth in sub-Saharan African (SSA) countries. To this end, panel data comprising 30 SSA countries were investigated for the period 1985-2019, using the system generalized method of moments (GMM) estimation technique. The study identified public investment, private investment and total factor productivity as channels transmitting the non-linear effect from external debt to economic growth. Furthermore, the interest rate was also confirmed as a channel but with a direct effect. Contrariwise, the estimates indicated that savings are not a channel of transmission from external debt to economic growth in SSA. These findings call for urgent action from SSA countries to reduce their external debt stocks and implement alternative macroeconomic non-debt strategies to improve the identified channels to counteract the negative effect of high external debt on them.
\end{abstract}

Keywords: channels of transmission; economic growth; external debt; sub-Saharan African countries

\section{Introduction}

Over the years, the relationship between external debt and economic growth has remained a significant issue widely discussed in the macro-economic literature (EdetNkpubre 2013). Expectedly, it has generated heated macro-economic debates between two major but opposing economic thought schools: the Keynesians and the neo-classical economists. The former posits that an increase in debt impacts growth positively and is necessary for economic recovery. A strand of the empirical literature supports this position on the subject, which holds that external debt positively impacts economic growth (Amin and Audu 2006; Bakar and Hassan 2008; Joshua et al. 2020; Ogunlana 2016; Pattillo et al. 2004). Contrariwise, neo-classical economists equate debt to a future tax and focus on the adverse effects of debt overload. Their view is corroborated by another strand of literature which suggests that external debt negatively affects economic growth (Ali and Mustafa 2012; Ciftcioglu and Sokhanvar 2018; Dey and Tareque 2019; Edo et al. 2020; Elbadawi et al. 1997; Karagol 2002; Soydan and Bedir 2015; Were 2001). Recently, however, attention has shifted towards investigating the non-linear effect of external debt on economic growth. The hypothesis that debt at moderate levels enhances growth, while in contrast, high debt stock depresses growth. In this strand of the empirical literature, studies by Asafo et al. (2019); Blavy (2006); Schclarek (2004); Schclarek and Ramon-Ballester (2005); Senadza et al. (2018) and Soydan and Bedir (2015) do not find evidence of a non-linear relationship between external debt and economic growth. In contrast, other studies, such as those by Adam and Bevan (2005); Cordella et al. (2005); Deshpande (1997); Pattillo et al. (2002), as well as Qureshi and Liaqat (2020), claim that the nexus follows a non-linear pattern.

In sub-Saharan Africa (SSA), the need to attain robust growth and sustainable development has led most economies in the region to adopt different policies and strategies at 
various stages of their development since attaining their independence. However, owing to distortions in the economic, financial and institutional arrangements in this region in the 1960s, recourse to external debt to galvanize the economies towards sustainable development became the norm from the 1970s onwards (Ouedraogo 2015). Over the past few decades, the region's external debt stock has increased significantly, making the debate on its role in financing the development process of these countries essential (Drine and Nabi 2010; World Bank 2010, 2017). Studies by Iyoha (1999), Loser (2004) and Ndikumana and Boyce (2011) document that from the 1980s, when the debt crisis involving several nations of the world occurred, external debt in African economies had reached unsustainable levels. These countries were simultaneously grappling with concomitant negative macroeconomic effects. The Heavily Indebted Poor Countries (HIPCs) initiative which the International Monetary Fund (IMF) and the World Bank inaugurated in 1996, was the first comprehensive campaign to terminate unsustainable debt and assist in a permanent exit from debt dependence among the poor economies of the world. Under this initiative, Western leaders agreed to write off large portions of several African nations' external debts. However, stocks of external debt have been increasing in most of these countries, following unbridled borrowing in recent years, coupled with the collapse in local currencies and commodity prices (World Bank 2010; World Bank 2017). For instance, Ghana's external debt stock, which stood at $139 \%$ of GNI in 2000 , reduced to $69 \%$ of GNI in 2005 , following the HIPC/E-HIPC initiatives. It even declined further to $28.8 \%$ of GNI in 2010 after the Multilateral Debt Relief Initiative (MDRI) intervention. However, as of 2015, it had surged to $56 \%$ of GNI and was still growing (World Bank 2017). Another noticeably big beneficiary of the debt forgiveness initiatives in SSA was Mozambique, which had its external debt slashed to $60 \%$ of GNI in 2005 -from $116 \%$ of GNI in 2000 . It declined further to $36 \%$ of GNI in 2011. However, as of 2015, it had increased to 69.5\% of GNI (World Bank 2017). Similar trends can be observed for other SSA countries like Angola, Cameroon, Gabon, Senegal and Zambia. While grappling with this conundrum, SSA countries have equally been inundated with a series of debt-rescheduling, which aggravated the debt crisis. In SSA, debt rescheduling dates back to the 1980s, and the total, which stood at USD 13.94 billion in 1989, rose to USD 22.63 billion by 2000. It nevertheless declined to USD 1.03 billion by 2007 due to the debt forgiveness initiative (Muhanji and Ojah 2011). However, it needs to be stated that there is ample evidence in the empirical literature that if procured sustainably and applied productively, foreign loans can be an ancillary to economic growth (Cassimon and Vaessen 2007; Claessens and Diwan 1990; Easterly 2002; Ferrarini 2008). Examples of countries that have employed debt productively for growth include South Korea, Chile, Brazil and Ghana (Muhanji and Ojah 2011).

As described in the debt cycle hypothesis, advanced by Avramovich (1964), external debt is considered crucial to stimulating investment in countries experiencing low savings. According to the abovementioned hypothesis, if managed properly, external debt would enhance domestic savings in the long-run, consequently promoting investment and paying back the foreign loans incurred earlier. However, it appears that many SSA countries are still trapped in the earlier stage, as the stock of external debt keeps increasing. At the same time, they remain beset by low domestic savings (Drine and Nabi 2010). Another important theory of debt is the debt overhang hypothesis which implies that external debt stock stimulates investment, which enhances economic growth when held at moderate levels. However, it hampers investment and, in turn, economic growth once it exceeds a certain threshold (Claessens and Diwan 1990; Cohen 1995; Krugman 1988; Sachs 1989).

Against this background, an emerging issue of interest among policy-makers and researchers revolves around the channels through which the effects of debt are transmitted to economic growth. However, empirical studies on this subject have been few and far between, with findings remaining inconclusive. For instance, in a panel study comprising 61 developing countries, Pattillo et al. (2004) document that external debt accumulation transmits its negative effect to economic growth through the channel of physical capital accumulation and total factor productivity growth, with total factor productivity growth 
accounting for a large portion of the impact. In contrast, capital accumulation contributes to a minuscule portion of the impacts. Another study by Riffat and Munir (2015) for four South Asian countries identifies transmission channels from public debt to economic growth as private investment, public investment, and total factor productivity. Furthermore, Pattillo et al. (2011) conclude that investment is the primary channel through which sizeable external debt transmits negative impact into the economy and not the investment level per se. However, they found some evidence for total factor productivity as a transmission channel between the two variables.

Meanwhile, in a more recent study, Qureshi and Liaqat (2020) identified savings and investment as the primary channels of impact from external debt to economic growth. Overall, the investigation of the channels through which external debt transmits its effect on economic growth has been inconclusive and has not received adequate attention in the literature. Indeed, no known previous study has investigated the subject with a focus on SSA countries. Thus, this study focuses on SSA countries for the following reasons. Since the 1980s, when SSA got enmeshed in an external debt conundrum, the region is yet to come out of it despite the various intervention policies to reverse the situation (World Bank 2020). Second, the region's external debt crisis is so enormous that as of 2020, the region constitutes $82 \%$ (32 out of 39 countries) of highly indebted poor countries of the world (World Bank 2020). Moreover, given the extremely different dimension of external debt crisis in the region, in terms of depth, compared to the rest of the world, conclusions on what constitute the channels of transmission from external debt to economic growth in SSA cannot be based solely on findings from studies on other regions. Especially given the fact that economic structures are not the same across regions. Therefore, this study contributes to the literature by identifying the channels of transmission in the external debt-economic growth nexus in SSA, which has not been considered in any previous study. This study would also add to the literature by determining whether the identified channels transmit linear or non-linear effect from external debt to economic growth. Most previous studies on the subject presumed linearity in their analysis. Establishing the transmission channels from external debt to economic growth in SSA would be useful in informing policy-makers in the region of the necessary macroeconomic non-debt strategies needed to improve the external debt-economic growth performance in the region.

This paper is organized as follows: Section 2 presents the literature review, Section 3 addresses the methodology, Section 4 presents and discusses the results, Section 5 presents the results of robustness tests, and Section 6 concludes the paper.

\section{Literature Review}

There is a growing interest amongst researchers and policy-makers concerning how debt's deleterious effect is transmitted into the economy. They have also been concerned about whether the non-linear effect of debt on growth is also obtainable in the relationship between debt and other factors that affect growth. There are, however, a limited quantity of research works on the channels of transmission in the relationship between debt and economic growth, especially as it concerns developing countries. In exploring the link between external debt and economic growth for fifty-nine developing and twenty-four industrial economies, Schclarek (2004) employed a panel data, using the system GMM econometric technique between the years 1970 and 2002. Results from their estimations indicated that debt accumulation affects growth primarily through capital accumulation growth. At the same time, there was limited evidence on external debt affecting growth through total factor productivity growth.

Moreover, mixed results were generated for private savings rates as a transmission channel between debt and growth. The estimations also rejected the claim of a non-linear relationship between external debt and economic growth. In contrast, no significant relationship was found between debt and growth for industrial countries. On the other hand, in a study by Silva (2020) on the effect of public and private external debt on economic growth in Portugal for the period 1999-2019, only public investment and private 
investment were established as the channels through which the effects of external debt are transmitted to economic growth. Other investigated channels comprising private saving, total factor productivity, private GVA in volume per person, and primary income account turned out insignificant and unaffected by external debt. The study also concluded that external debt did not substantially affect the inputs of the production function. In a similar type of study, Pattillo et al. (2004) used the OLS, instrumental variable, fixed effects, differenced GMM and system GMM approaches within a growth accounting framework to analyse the channels through which debt affects growth for sixty-one developing countries, with panel data covering the period 1969 to 1998 . From the results of their analysis, they concluded that high debt affects economic growth negatively via the channels of physical capital accumulation and total factor productivity growth. They further claimed that almost one-third of the negative effect of debt on growth occurs through the channel of physical capital accumulation. In contrast, about two-thirds occur through the channel of total factor productivity growth. Meanwhile, in a study of the relationship between external debt and economic growth for 123 countries for the period 1990-2015 using panel VAR model, Qureshi and Liaqat (2020), established savings and investment the primary channel of impact from external debt to economic growth.

Furthermore, an examination of the average impact of public debt on per capita GDP growth was carried out by Checherita-Westphal and Rother (2012) for twelve Euro area countries over a period of almost 40 years starting in 1970. Using dynamic panel models, they concluded that the channels through which debt affects growth are private saving, total factor productivity, public investment and sovereign long-term nominal and real interest rates. The claim that savings and interest rate are channels through which debt affects economic growth was rejected in another, later study by Riffat and Munir (2015) for four Asian countries covering the period 1991 to 2013. Estimation results from the fixed effect technique showed that the channels through which debt negatively affects growth are private investment, public investment and total factor productivity. In their estimations, savings and interest rates fail to be significant transmission channels between public debt and growth. They also claim that the relationship between debt and growth in South Asian countries is non-linear.

Furthermore, by focusing on fifty-five low-income countries between 1970 and 1999, the channels through which external debt affects economic growth were investigated by Clements and Krolzig (2003). Using the econometric techniques of fixed effects and system GMM, they reported that external debt negatively affects growth through its adverse impact on public investment. Their estimations also confirmed the existence of debt overhang and the non-linear effect of debt on growth in countries' sample. Moreover, in a study of the channels through which public debt affects growth in thirty-eight advanced and emerging economies for the period 1970-2007, Kumar and Woo (2010) employed pooled OLS, between estimator, fixed effects and system GMM. Their estimated results concluded that a negative relationship between debt and growth is mostly explained by a decrease in labor productivity growth caused by a decline in investments and capital stock growth.

Furthermore, several studies have investigated the debt-growth nexus through its relationship with investment. In one of these studies, Borensztein (1990) used numerical simulations of a rational expectations growth model for a heavily indebted country and argued that past accumulated debts lead to debt overhang and that credit rationing may be a major discouragement to investment. Similarly, by investigating the investment experience of thirteen heavily indebted economies between 1971 and 1991, the debt overhang hypothesis was explored by Deshpande (1997). Using the fixed effects approach, he discovered that the relationship between external debt and investment was consistently negative. Additionally, his analysis revealed that investment is affected by external debt in as many ways as other determinants of investment affect it, especially in economies suffering from debt overhang. Meanwhile, in opposition to these findings that indicate investment as a channel between debt and growth, a panel study for ninety-three developing countries that cut across sub-Saharan Africa, Asia, Latin America and the Middle East was conducted 
by Pattillo et al. (2011) over the period 1969 to 1998. Findings from their fixed effects and system GMM estimations meant that they rejected the claim that investment is the main channel through which external debt transmits a negative impact on the economy.

In conclusion, while there is a preponderance of claims in the literature that investment constitutes a channel of transmission between external debt and economic growth, findings are divergent on whether other variables are indeed channels of transmission between the two variables. The review also clarifies that investigation of the subject for SSA has not received adequate attention in the literature; hence, the need for this study.

\section{Methodology}

\subsection{Estimation Technique}

This study's empirical objective revolves around investigating the channels that are capable of spreading the effect of external debt on economic growth. In line with extant literature (Checherita-Westphal and Rother 2012; Pattillo et al. 2004; Riffat and Munir 2015; Schclarek 2004; Silva 2020), this study tests the channels of public investment, private investment, total factor productivity, savings and interest rate by way of investigating the impact of external debt on each of the variables. The significance of each model's external debt variable(s) would serve to confirm whether or not the variable indeed serves as a channel in the external debt-economic growth nexus for the sampled countries. For each of the channels, the following dynamic model was employed:

$$
Z_{i t}=\vartheta_{0 i}+\vartheta_{1 i} Z_{i, t-1}+\vartheta_{2 i} E D_{i t}+\vartheta_{3 i} E D_{i t}^{2}+\vartheta_{4 i} X_{i t}+\mu_{i}+\varepsilon_{i t}
$$

where $i$ and $t$ are cross-sectional units and the period respectively, $Z$ is the channel being investigated, $E D$ and $E D^{2}$ are the external debt variable and its squared term, respectively, $X$ is a vector of control variables which include private investment, public investment, trade openness, interest rate, real GDP per capita and population growth rate, $Z_{i, t-1}$ is the lagged dependent variable, $\mu_{i}$ is the individual country-specific effect, which captures unobserved heterogeneities among the countries and $\varepsilon$ is the error term. Different control variables are included in each of the models to account for each channel's covariates being tested as established in the literature (Checherita-Westphal and Rother 2012; Riffat and Munir 2015; Schclarek 2004; Silva 2020). Thus, each model's control variables serve to evaluate whether the impact of external debt on the respective dependent variables remains the same after accounting for the effects of these covariates on the dependent variables. All variables are expressed in their logarithmic forms.

The squared term of the external debt variable is included in the model to determine whether the channel under consideration transmits a non-linear effect from external debt to economic growth. Thus, for the transmission channel to be adjudged as transmitting non-linear impact, $\vartheta_{2 i}$ and $\vartheta_{3 i}$ must be significant and bear opposite signs. Suppose they were both significant with the former and the latter being negative and positive signs. In that case, the relationship is U-shaped or convex. On the other hand, if they were both significant with the former and the latter being positive and negative, respectively, then the relationship is inverted U-shaped or concave. From the equation, the external debt threshold can be estimated (in the case of both coefficients being significant and bearing opposite signs) by finding the first-order partial derivative of Equation (1) concerning external debt and setting the same equal to zero to obtain Equation (2) as the external debt threshold:

$$
\frac{\partial Z_{i t}}{\partial E D_{i t}}=\frac{-\vartheta_{2 i}}{2 \vartheta_{3 i}}
$$

Given the inclusion of the lagged dependent variable $\left(Z_{i, t-1}\right)$ in Equation (1), as well as an high possibility of the presence of endogeneity in the model as established in the literature (Gomez-Puig and Sosvilla-Rivero 2017; Kourtellos et al. 2013; Panizza and Presbitero 2014; Pattillo et al. 2011; Pescatori et al. 2014) regarding debt variables often used in econometric models, the use of standard static panel data estimation techniques such as pooled OLS, fixed effects and random effects would not be appropriate for this study. To 
address these issues, the generalized method of moments (GMM) is proposed by Arellano and Bond (1991), who suggests the first differencing of Equation (1) to obtain:

$$
\Delta Z_{i t}=\varnothing_{1 i} \Delta Z_{i t-1}+\varnothing_{2 i} \Delta E D_{i t}+\varnothing_{3 i} \Delta E D_{i t}^{2}+\varnothing_{4 i} \Delta X_{i t}+\Delta \varepsilon_{i t}
$$

Although by first-differencing the models as shown in Equation (3), the potential linear correlations between lagged dependent variable, $Z_{i t-1}$ and the individual countryspecific effect, $\mu_{i}$, have been removed, the problem of endogeneity persists, which arises from the linear correlation between the lagged dependent variable, $\Delta Z_{i t-1}$ and the new error term, $\Delta \varepsilon_{i t}$ (that is, $E\left[\Delta Z_{i t-1} . \Delta \varepsilon_{i t}\right] \neq 0$ ). To overcome this problem, Arellano and Bond (1991) suggest using the lagged values of the explanatory variables in levels as instruments. Therefore, if $A$ denotes a matrix of explanatory variables, the following moment conditions are:

$$
E\left[A_{i, t-s} \cdot \Delta \varepsilon_{i t}\right]=0 \text { for } s \geq 2 ; t=3, \ldots, T
$$

With these moment restrictions, one-step and two-step difference GMM estimators were proposed by Arellano and Bond (1991). In the one-step estimator, he assumes the error terms to be both independent and homoscedastic across individual units and over time, while in the two-step estimator, the assumptions of independence and homoscedasticity are relaxed by employing the residuals derived from the one-step estimator to formulate a consistent estimate of the variance-covariance matrix. Therefore, the difference GMM technique is advantageous, given its ability to overcome the problems of simultaneity bias and the country-specific effect. Nevertheless, it has been argued by Blundell and Bond (1998) that it can lead to faulty inferences because lagged levels of dependent and explanatory variables are weak instruments if these variables are persistent over time. To overcome this limitation, the system GMM was proposed by Arellano and Bover (1995) and Blundell and Bond (1998). According to them, it combines both the first-difference and level equations with the lagged levels of the explanatory variables serving as the instruments for the level equations. The validity of the instruments hinged on the assumption that the correlation between the country-specific effect and the levels of the regressors is constant over time, such that:

$$
E\left[A_{i, t+p}, \mu_{i}\right]=E\left[A_{i, t+q}, \mu_{i}\right] \quad \text { for all } p \text { and } q
$$

With this assumption, the country-specific effect and the differences of the regressors are uncorrelated. For example, this assumption connotes that external debt and the countryspecific effect may be correlated, but this correlation is constant over time. The moment conditions for the levels regressions in this study can, therefore, be stated as follows:

$$
E\left[\left(\Delta A_{i, t-s}\right) \cdot\left(\varepsilon_{i t}+\mu_{i}\right)\right]=0 \text { for } s=1 ; t=3, \ldots, T
$$

Thus, the system GMM comprises two regressions, one in differences and the other in levels. While the moment conditions in Equation (4) apply to the regression in differences or the first part of the system, the moment conditions in Equation (6) apply to the regressions in levels or the second part of the system. The system GMM are of two types, the one-step system GMM and the two-step system GMM. The two-step variant is applied in this study because it is more efficient than its one-step variant. It uses optimal weighting matrices, thereby yielding more efficient and consistent parameter estimates. For each model in the study, the GMM instrument employed is a one-period lagged value of the logged dependent variable. Furthermore, the internal instruments, which are employed in all the models based on their past realizations (Beck et al. 2000) comprise log of private investment (percentage of GDP), log of trade (percentage of GDP) and log of population growth rate.

In order to verify the consistency of the GMM estimator, two specification tests were conducted, namely the Hansen J-statistic for over-identifying restriction and the ArellanoBond test (AR(2)) for autocorrelation in the disturbances (Arellano and Bond 1991). To 
confirm that the GMM estimator is consistent, the Hansen J statistic null hypothesis that the instrumented variables are exogenous and not correlated with the error term must not be rejected. Equally, The AR(2) null hypothesis that the model does not suffer from second-order serial correlation must also not be rejected; otherwise, the GMM estimator's assumption becomes violated.

One of the fundamental conditions for adopting the GMM as the estimation technique is that the number of cross sections $(\mathrm{N})$ must be higher than that of time-series observation (T), such that the dimension of the dataset should be large $\mathrm{N}$ and small $\mathrm{T}$ (Roodman 2009). In order to comply with this condition, a four-year averaged data is used thereby giving nine observations for each country with the last observation being a three-year averaged data, in line with the trend in the literature (Beck et al. 2000; Gazdar and Cherif 2015; Hassan et al. 2019; Law et al. 2018; Olaniyi and Oladeji 2020). The nine observations are 1985-1988, 1989-1992, 1993-1996, 1997-2000, 2001-2004, 2005-2008, 2009-2012, 2013-2016 and 2017-2019. According to Roodman (2009), not averaging the data in this kind of situation can lead to an upsurge in the number of instruments that could cause too many instruments. Averaging the years is also advantageous. It helps to mitigate the effects of the business cycle phenomenon, leading to biased estimates from GMM estimators (Beck et al. 2000; Law et al. 2018).

\subsection{Data}

This study employed panel data covering 35 years from 1985 to 2019 for a sample of 30 SSA countries (see Appendix A for the list of countries). The choice of 1985 as the starting period was informed that SSA experienced the beginning of an upsurge in external debt accumulation and a massive slowdown in economic growth during the 1980s. Moreover, 30 SSA countries were captured because of the paucity of relevant data for the remaining SSA countries. External debt was measured by three variables: external debt/GDP ratio, external debt/export ratio and interest payment/export ratio. Private investment and public investment were measured by gross fixed capital formation as a percentage of GDP generated by the private and public sectors, respectively. Economic growth was measured by real GDP per capita (constant 2010 USD). Data on the three variables and that of interest rate (measured by real interest rate), trade openness/GDP ratio and population growth were sourced from World Development Indicators (WDI). While data on savings, represented by gross savings, were sourced from World Economic Outlook (WEO). Data on total factor productivity was collected from the Penn World Table (PWT), Version 10.0.

\section{Empirical Results}

\subsection{Descriptive Statistics}

A summary of the descriptive statistics of the variables employed in all the models is reported in Table 1. The mean GDP per capita for the sample is USD 1538.37. The highest real GDP per capita of USD 12,042.43 was recorded by Gabon as far back as 1985, while Mozambique recorded the lowest figure of USD 131.65 in 1986. The external debt variables peaked at 1380.77/GDP, 4245.39/export and 43.83/export for external debt/GDP, external debt/export and interest payment/export and they were recorded by Liberia in 2003, Sudan in 1993 and Guinea-Bissau in 1987, respectively. The average values of private investment, public investment, total factor productivity, interest rate and savings are 13.14/GDP, 8.05/GDP, 0.97, 25.15 and 14.21/GDP. The standard deviation measures the degree to which variables disperse from their mean. Figures from the Table show that most of the variables are very stable, as reflected in their standard deviation figures. 
Table 1. Descriptive statistics.

\begin{tabular}{cccccc}
\hline Variable & Mean & Std. Dev. & Minimum & Maximum & Obs. \\
\hline GDP & 1538.37 & 2155.93 & 131.65 & $12,042.43$ & 1050 \\
EDG & 99.26 & 128.15 & 3.89 & 1380.77 & 1050 \\
EDX & 401.27 & 555.01 & 6.26 & 4245.39 & 1050 \\
EDI & 5.33 & 5.99 & 0.08 & 43.83 & 987 \\
PRI & 13.14 & 6.54 & -4.08 & 50.16 & 970 \\
PUI & 8.05 & 9.25 & 0 & 74.61 & 1050 \\
TFP & 0.97 & 0.19 & 0.41 & 1.71 & 985 \\
INT & 25.15 & 59.93 & 4.74 & 1175 & 1050 \\
SAV & 14.21 & 11.02 & -30.11 & 53.22 & 1050 \\
TRD & 63.65 & 30.49 & 9.14 & 311.35 & 1050 \\
POP & 2.32 & 0.84 & -1.84 & 7.85 & 1050
\end{tabular}

Note: GDP = real GDP per capita, EDG = external debt/GDP, EDX = external debt/export, EDI = interest payment/ export, $\mathrm{PRI}=$ private investment, $\mathrm{PUI}=$ public investment, $\mathrm{TFP}=$ total factor productivity, $\mathrm{INT}=$ interest rate, $\mathrm{SAV}=$ savings, $\mathrm{TRD}=$ trade openness, $\mathrm{POP}=$ population growth.

\subsection{Estimation and Discussion}

Table 2 reports the results of the system GMM estimation of the model. Results from models with private investment, public investment, total factor productivity (TFP), interest rate and savings as dependent variables are presented in columns (2), (3), (4), (5) and (6), respectively. In each of the five equations, the lagged dependent variable's coefficient is statistically significant at $1 \%$, indicating the persistence and path-dependency of all the dependent variables in the countries under consideration. The diagnostic tests conducted also show that the probability values of AR(2) tests in all the five models are greater than $5 \%$, which implies that all the models are free from the problem of second-order serial correlation. The results also show that both Sargan and Hansen tests yield insignificant probability values in all the five models. This implies that the instruments employed in all the models are adequate and are not over-identified.

The private investment model estimates in column 2 show that the external debt variable's coefficient is positive. At the same time, that of its squared term is negative. Furthermore, while the former is statistically significant, at $1 \%$, the latter is significant, at $5 \%$. These results indicate an inverted U-shaped relationship between external debt and private investment, which suggests that the non-linear effect of external debt on economic growth is transmitted through private investment. The turning point beyond which external debt begins to affect private investment negatively is estimated as $65.42 \%$ of $\operatorname{GDP}(0.003271 / 0.000050=65.42)$, in line with Equation (2). This result indicates that private investment begins to transmit a negative impact from external debt to economic growth beyond this threshold of external debt. The negative effect of external debt above this threshold can be explained by the fact that as the economy's external debt stock increases, existing and prospective investors anticipate the imposition of higher and new taxes by the government. This would decrease the investors' expectations regarding returns on their investment and discourage new private investment in the economy. Another argument for the negative effect of external debt on private investment beyond the threshold is that huge debt accumulation could signal higher uncertainty about the economy, which could discourage foreign direct investment. This finding corroborates Qureshi and Liaqat (2020), Riffat and Munir (2015) and Silva (2020) but contradicts Checherita-Westphal and Rother (2012). The coefficient of public investment is negative and statistically significant at the $1 \%$ level, indicating an increase in public investment leads to a decline in private investment. In this case, public investment could be said to be crowding out private investment. While trade openness enhances private investment, the interest rate is found to impact it negatively. The coefficient of real GDP per capita is positive and significant at $1 \%$, which implies that positive economic growth enhances private investment.

For the public investment model in column 3, the estimates indicate that public investment constitutes a channel for transmitting external debt's non-linear effect to economic 
growth, given the significance and opposite signs of the external debt variables. The external debt turning point is computed at $33.01 \%$ of GDP $(0.037105 / 0.001124=33.01)$. The negative effect of external debt above this threshold can be explained by the fact that huge debt accumulation is accompanied by a high debt servicing burden, leading to a reduction in capital expenditure for the economy. Thus exerting a negative impact on the infrastructural development, which is much needed to stimulate economic growth. This finding is in line with Checherita-Westphal and Rother (2012), Qureshi and Liaqat (2020), Riffat and Munir (2015) and Silva (2020). The coefficient of private investment is negative and significant at the $1 \%$ level, indicating a negative effect of private investment on public investment. The coefficients of interest rate and population growth rate are both insignificant, indicating that both variables have no impact on public investment. Meanwhile, economic growth has a weak positive effect on public investment, going by the coefficient of real GDP per capita being positive and significant at $10 \%$.

The estimates of the TFP model, as reported in column 4, show that both the external debt variable and its squared term are significant at $5 \%$ and $10 \%$ levels, respectively. While the former bears a positive sign, the latter bears a negative sign, thereby indicating a case of non-linear and inverted U-shaped relationship between external debt and TFP. The external debt threshold is computed at $82.88 \%$ of GDP $(0.003315 / 0.000040=82.88)$. Above this threshold, the TFP transmits a negative impact from external debt to economic growth. The negative effect of external debt above this threshold could emanate from possible government reluctance to initiate and implement expensive economic reforms, especially when it is believed that most gains from such reforms and policies would accrue to the external debt creditors, rather than to the citizens. In the absence of such reforms, productivity might decline, which could cause economic growth to slow down. From another perspective, debt overhang from huge external debt accumulation often culminates in growing economic uncertainties, which could dis-incentivize technology investment (Pattillo et al. 2004). This could in turn, produce a negative effect on TFP, and subsequently on economic growth. This result is in line with some previous findings (Checherita-Westphal and Rother 2012; Pattillo et al. 2004; Riffat and Munir 2015), while it contradicts Schclarek (2004) and Silva (2020). The coefficients of private investment and real GDP per capita are positive and significant at the $1 \%$ level, which implies that higher investment levels in the private sector and economic growth are associated with improvement in TFP. On the other hand, the interest is negative and significant, showing that increase in interest rates dampens TFP.

The interest rate model's results are reported in column 5 . They show that external debt is positive and significant at the $1 \%$ level. At the same time, its squared term is negative and insignificant. This demonstrates that external debt exerts a direct effect on interest rate rather than a non-linear effect. The interest rate is adjudged as a channel for transmitting a linear effect from external debt to economic growth. This implies that regardless of the level of external debt, its effect on interest rate is direct. It is expected to transmit a negative impact on economic growth subsequently. This result does not support findings in existing studies by Checherita-Westphal and Rother (2012) and Riffat and Munir (2015), which claim that interest rate is not a channel of transmission from external debt to economic growth in the Euro area and South Asia, respectively. The coefficients of trade openness and GDP per capita are significant at $5 \%$ and $1 \%$, respectively. While the former is positive, the latter bears a negative coefficient. This indicates that greater openness to international trade leads to an increase in the interest rate. Simultaneously, positive growth in the economy is associated with a reduction in the interest rate, which indicates that both variables positively affect the interest rate. Meanwhile, the population growth rate is insignificant, indicating that it has no impact on the interest rate.

In column 6, containing the savings model, the results indicate that both the external debt variable and its squared term are insignificant. These results indicate that external debt does not affect savings; hence, savings are not channels through which external debt transmits its impact on economic growth. This result is in line with some previous 
findings (Riffat and Munir 2015; Schclarek 2004; Schclarek and Ramon-Ballester 2005; Silva 2020) but opposes those of Qureshi and Liaqat (2020) and Checherita-Westphal and Rother (2012). They identified savings as a channel of transmission from external debt to economic growth. The interest rate coefficient is negative and significant at $1 \%$, which implies that a $1 \%$ increase in the interest rate dampens savings by $0.15 \%$. Furthermore, real GDP per capita and population growth are positive and significant at $5 \%$ and $1 \%$ respectively, thus implying that a percentage increase in real GDP per capita and population growth are associated with 0.12 and 0.33 increase respectively in savings.

Table 2. Panel regression results (External debt (ED) = external debt/GDP).

\begin{tabular}{|c|c|c|c|c|c|}
\hline $\begin{array}{c}\text { Dependent } \\
\text { Variable }\end{array}$ & PRI & PUI & TFP & Interest Rate & Savings \\
\hline (1) & (2) & (3) & (4) & (5) & (6) \\
\hline$Z_{t-1}$ & $\begin{array}{c}0.250071^{* * *} \\
(0.016671)\end{array}$ & $\begin{array}{c}0.143307^{* * *} \\
(0.017692)\end{array}$ & $\begin{array}{c}0.118219 * * * \\
(0.025153)\end{array}$ & $\begin{array}{c}0.224131 \text { *** } \\
(0.037988)\end{array}$ & $\begin{array}{c}0.102417^{* * *} \\
(0.023873)\end{array}$ \\
\hline ED & $\begin{array}{c}0.003271^{* * *} \\
(0.000485)\end{array}$ & $\begin{array}{c}0.037105^{* * *} \\
(0.011595)\end{array}$ & $\begin{array}{l}0.003315^{* *} \\
(0.001507)\end{array}$ & $\begin{array}{c}0.001708^{* * *} \\
(0.000427)\end{array}$ & $\begin{array}{l}-0.031541 \\
(0.113417)\end{array}$ \\
\hline ED2 & $\begin{array}{c}-0.000025^{* *} \\
(0.000012)\end{array}$ & $\begin{array}{c}-0.000562^{* *} \\
(0.000275)\end{array}$ & $\begin{array}{c}-0.000020^{*} \\
(0.000011)\end{array}$ & $\begin{array}{c}0.000021 \\
(0.000013)\end{array}$ & $\begin{array}{c}0.000031 \\
(0.000074)\end{array}$ \\
\hline PUI & $\begin{array}{c}-0.180021^{* * *} \\
(0.023079)\end{array}$ & & & & \\
\hline PRI & & $\begin{array}{c}-0.153207^{* * *} \\
(0.025116)\end{array}$ & $\begin{array}{c}0.001733^{* * *} \\
(0.000578)\end{array}$ & & \\
\hline TRD & $\begin{array}{c}0.082214^{* * *} \\
(0.024181)\end{array}$ & & & $\begin{array}{l}0.005711^{* *} \\
(0.002731)\end{array}$ & \\
\hline INT & $\begin{array}{c}-0.287155^{* * *} \\
(0.042229)\end{array}$ & $\begin{array}{c}-0.000253 \\
(0.003507)\end{array}$ & $\begin{array}{c}-0.001327 \text { ** } \\
(0.000651)\end{array}$ & & $\begin{array}{c}-0.154071 \text { *** } \\
(0.037578)\end{array}$ \\
\hline GDP & $\begin{array}{c}0.005271^{* * * *} \\
(0.002475)\end{array}$ & $\begin{array}{l}0.027114 \text { * } \\
(0.014656)\end{array}$ & $\begin{array}{c}0.005341^{* * *} \\
(0.000785)\end{array}$ & $\begin{array}{c}-0.017307^{* * *} \\
(0.004438)\end{array}$ & $\begin{array}{l}0.118320 * * \\
(0.058866)\end{array}$ \\
\hline POP & & $\begin{array}{c}0.001527 \\
(0.237142)\end{array}$ & $\begin{array}{c}0.000571 \\
(0.011705)\end{array}$ & $\begin{array}{c}0.014361 \\
(0.023171)\end{array}$ & $\begin{array}{c}0.331427^{* * *} \\
(0.114285)\end{array}$ \\
\hline $\begin{array}{l}\text { Threshold of } \\
\text { external debt }\end{array}$ & $\begin{array}{l}65.42 \% \text { of } \\
\text { GDP }\end{array}$ & $\begin{array}{c}33.01 \% \text { of } \\
\text { GDP }\end{array}$ & $\begin{array}{c}82.88 \% \text { of } \\
\text { GDP }\end{array}$ & - & - \\
\hline $\begin{array}{c}\text { No of } \\
\text { Instruments }\end{array}$ & 27 & 27 & 27 & 27 & 27 \\
\hline $\begin{array}{l}\text { AR(1): } \\
p \text {-value }\end{array}$ & 0.051 & 0.012 & 0.512 & 0.022 & 0.131 \\
\hline $\begin{array}{c}\text { AR(2): } \\
p \text {-value }\end{array}$ & 0.213 & 0.412 & 0.604 & 0.331 & 0.105 \\
\hline $\begin{array}{c}\text { Sargan test: } \\
p \text {-value }\end{array}$ & 0.308 & 0.211 & 0.251 & 0.417 & 0.614 \\
\hline $\begin{array}{c}\text { Hansen test: } \\
p \text {-value }\end{array}$ & 0.117 & 0.404 & 0.281 & 0.307 & 0.281 \\
\hline
\end{tabular}

Notes: All variables are in logarithm form; ${ }^{*},{ }^{* *}$ and ${ }^{* * *}$ represent significance at $10 \%, 5 \%$ and $1 \%$, respectively; $Z_{t-1}=$ lagged dependent variable, $\mathrm{PRI}=$ private investment, $\mathrm{PUI}=$ public investment, $\mathrm{TFP}=$ total factor productivity, $\mathrm{ED}=$ external debt, $\mathrm{ED} 2=$ squared external debt, $\mathrm{TRD}=$ trade openness, $\mathrm{INT}=$ interest rate, $\mathrm{GDP}=$ real GDP per capita, $\mathrm{POP}$ = population growth; Values in parentheses represent standard errors.

\section{Robustness Tests}

To check the robustness of estimates, each of the five models was re-estimated with two alternative measures of external debt: external debt/export ratio and interest payment on external debt/export ratio, using the system GMM estimator. All the ten equations in Tables 3 and 4 pass the relevant diagnostic tests. As all AR(2) probability values, Sargan and 
Hansen tests are higher than 5\%. This implies that all the models are free from second-order serial correlation, while the instruments employed are also adequate. As reported in Table 3, private investment, public investment, TFP, interest rates and savings models corroborate those of the main regressions when external debt/export ratio is employed as the external debt variable. The private investment model results are presented in column (2) of the Table. They indicate that private investment transmits a non-linear impact from external debt to economic growth. The threshold of external debt beyond which private investment begins to transmit a negative impact from external debt to economic growth is computed at $345.06 \%$ of export $(0.005521 / 0.000016=345.06)$. For the public investment model reported in column (3), the dependent variable is also found to transmit a non-linear impact from external debt to economic growth, with the threshold beyond which public investment begins to transmit a negative impact from external debt to economic growth computed at $138 \%$ of export $(0.000552 / 0.000004=138)$. The TFP model estimates in column $(4)$ also report TFP as constituting a channel of non-linear effect from external debt to economic growth. The turning point of external debt beyond which an adverse effect is transmitted from TFP to economic growth is computed at $158.76 \%$ of export $(0.025719 / 0.000162=$ 158.76). As for the interest rate model reported in column (5), the interest rate is found to transmit a direct impact of external debt on economic growth. It is reported in column (6) that savings are not a channel of transmission from external debt to economic growth.

On the other hand, when interest payment/export ratio is the external debt variable reported in Table 4, results from private investment, public investment, TFP and savings models conform to those in the main regression. The results indicate that private investment, public investment and TFP reported in columns (2), (3) and (4), respectively, transmit non-linear impact from external debt servicing to economic growth. At the same time, they also indicate that savings, reported in column (6), is not a channel of transmission from external debt servicing to economic growth. The thresholds of external debt beyond which each channel begins to transmit a negative impact from external debt servicing to economic growth is computed at $8 \%$ of export $(0.008873 / 0.001110=7.99), 12.01 \%$ of export $(0.001873 / 0.000156=12.01)$ and $7.50 \%$ of export $(0.021831 / 0.002910=7.50)$ for the channels of private investment, public investment and TFP, respectively. The results of the interest rate model reported in column (5) do not conform to those of the main regression, as they indicate that the interest rate does not transmit the effect of external debt servicing to economic growth, and this is in line with previous results from Checherita-Westphal and Rother (2012) and Riffat and Munir (2015). Apart from this, results from the robustness tests are generally similar to those of the primary regression, thereby confirming that the estimates are robust to alternative external debt measures.

Looking at the threshold levels of external debt as displayed in Table 2, the highest threshold obtained when external debt/GDP ratio is the external debt variable is $82.88 \%$ of GDP, while the lowest obtained is $33.01 \%$ of GDP for the TFP and public investment models respectively. This result implies that public investment is much more sensitive than private investment and TFP. It begins to transmit a negative effect on economic growth once external debt accumulation reaches $33.01 \%$ of GDP. This implication is corroborated by the threshold levels of external debt when external debt/export is the external debt variable, as displayed in Table 3, where the public investment channel threshold is by far the lowest at $138 \%$ of export. In comparison, those of private investment and TFP are $345.06 \%$ of export and $158.76 \%$ of export, respectively. These results imply that to prevent the transmission of negative impacts from the identified channels, SSA countries should endeavor to hold external debt stock below $33.01 \%$ of GDP and $138 \%$ of export. The thresholds of external debt when interest payment/export ratio is the external debt ratio are displayed in Table 4. The thresholds range from $7.5 \%$ to $12.01 \%$, with TFP appearing to be the most sensitive and public investment the least sensitive. In this case, to prevent the transmission of negative impact of high external debt on economic growth through the identified channels, the interest payment on external debt by SSA countries should not exceed $7.5 \%$ of export. 
Table 3. Panel regression results (External debt (ED) = external debt/export).

\begin{tabular}{|c|c|c|c|c|c|}
\hline $\begin{array}{l}\text { Dependent } \\
\text { Variable }\end{array}$ & PRI & PUI & TFP & Interest Rate & Savings \\
\hline (1) & (2) & (3) & (4) & (5) & (6) \\
\hline$Z_{t-1}$ & $\begin{array}{c}0.156071^{* * * *} \\
(0.031214)\end{array}$ & $\begin{array}{c}0.551361 \text { *** } \\
(0.149016)\end{array}$ & $\begin{array}{c}0.147373^{* * *} \\
(0.030076)\end{array}$ & $\begin{array}{c}0.317008^{* * *} \\
(0.090574)\end{array}$ & $\begin{array}{c}0.201411 \text { *** } \\
(0.064971)\end{array}$ \\
\hline ED & $\begin{array}{c}0.005521^{* * *} \\
(0.001972)\end{array}$ & $\begin{array}{c}0.000552 * * * \\
(0.000063)\end{array}$ & $\begin{array}{l}0.025719 * * \\
(0.003099)\end{array}$ & $\begin{array}{c}0.001804^{* * *} \\
(0.000644)\end{array}$ & $\begin{array}{l}-0.015227 \\
(0.170143)\end{array}$ \\
\hline ED2 & $\begin{array}{c}-0.000008^{* *} \\
(0.000004)\end{array}$ & $\begin{array}{c}-0.000002^{* *} \\
(0.000001)\end{array}$ & $\begin{array}{c}-0.000081 * \\
(0.000042)\end{array}$ & $\begin{array}{c}0.000507 \\
(0.015207)\end{array}$ & $\begin{array}{c}0.000019 \\
(0.025871)\end{array}$ \\
\hline PUI & $\begin{array}{c}-0.032127^{* * *} \\
(0.005636)\end{array}$ & & & & \\
\hline PRI & & $\begin{array}{c}-0.055271 * * \\
(0.026319)\end{array}$ & $\begin{array}{c}0.017394^{* * *} \\
(0.008697)\end{array}$ & & \\
\hline TRD & $\begin{array}{l}0.000217 \text { * } \\
(0.000114)\end{array}$ & & & $\begin{array}{c}0.014308 \\
(0.231047)\end{array}$ & \\
\hline INT & $\begin{array}{c}-0.142111^{* * * *} \\
(0.022921)\end{array}$ & $\begin{array}{c}-0.001164 \\
(0.013500)\end{array}$ & $\begin{array}{c}0.015222 * * * \\
(0.004477)\end{array}$ & & $\begin{array}{c}-0.122710^{* * * *} \\
(0.033165)\end{array}$ \\
\hline GDP & $\begin{array}{c}0.017280 \text { *** } \\
(0.005760)\end{array}$ & $\begin{array}{l}0.152027 * \\
(0.049041)\end{array}$ & $\begin{array}{c}0.024111^{* * * *} \\
(0.008611)\end{array}$ & $\begin{array}{c}-0.000152 * * * \\
(0.000031)\end{array}$ & $\begin{array}{l}0.007182 * * \\
(0.003591)\end{array}$ \\
\hline POP & & $\begin{array}{c}0.015293 \\
(0.237142)\end{array}$ & $\begin{array}{c}0.003180 \\
(0.011705)\end{array}$ & $\begin{array}{l}0.032806 \text { ** } \\
(0.015049)\end{array}$ & $\begin{array}{c}0.174111 \text { *** } \\
(0.019563)\end{array}$ \\
\hline $\begin{array}{l}\text { Threshold of } \\
\text { external debt }\end{array}$ & $\begin{array}{c}345.06 \% \text { of } \\
\text { export }\end{array}$ & $\begin{array}{c}138 \% \text { of } \\
\text { export }\end{array}$ & $\begin{array}{c}158.76 \% \text { of } \\
\text { export }\end{array}$ & - & - \\
\hline $\begin{array}{c}\text { No of } \\
\text { Instruments }\end{array}$ & 27 & 27 & 27 & 27 & 27 \\
\hline $\begin{array}{c}\text { AR(1): } \\
p \text {-value }\end{array}$ & 0.032 & 0.055 & 0.221 & 0.102 & 0.094 \\
\hline $\begin{array}{l}\text { AR(2): } \\
p \text {-value }\end{array}$ & 0.111 & 0.372 & 0.403 & 0.263 & 0.137 \\
\hline $\begin{array}{l}\text { Sargan test: } \\
p \text {-value }\end{array}$ & 0.210 & 0.173 & 0.421 & 0.624 & 0.370 \\
\hline $\begin{array}{c}\text { Hansen test: } \\
p \text {-value }\end{array}$ & 0.279 & 0.371 & 0.281 & 0.531 & 0.183 \\
\hline
\end{tabular}

Notes: All variables are in logarithm form; ${ }^{*},{ }^{* *}$ and ${ }^{* * *}$ represent significance at $10 \%, 5 \%$ and $1 \%$, respectively; $Z_{t-1}=$ lagged dependent variable, $\mathrm{PRI}=$ private investment, $\mathrm{PUI}=$ public investment, $\mathrm{TFP}=$ total factor productivity, $\mathrm{ED}=$ external debt, $\mathrm{ED} 2$ = squared external debt, $\mathrm{TRD}=$ trade openness, $\mathrm{INT}$ = interest rate, GDP = real GDP per capita, $\mathrm{POP}=$ population growth; Values in parentheses represent standard errors.

Table 4. Panel regression results (External debt (ED) = interest payment/export).

\begin{tabular}{cccccc}
\hline $\begin{array}{c}\text { Dependent } \\
\text { Variable }\end{array}$ & PRI & PUI & TFP & Interest Rate & Savings \\
\hline $\mathbf{( 1 )}$ & $\mathbf{( 2 )}$ & $\mathbf{( 3 )}$ & $\mathbf{( 4 )}$ & $\mathbf{( 5 )}$ & $\mathbf{( 6 )}$ \\
\hline$Z_{t-1}$ & $0.115704^{* * *}$ & $0.153207^{* * *}$ & $0.603737^{* * *}$ & $0.422108^{* * *}$ & $0.271008^{* * *}$ \\
& $(0.017269)$ & $(0.051069)$ & $(0.116103)$ & $(0.089810)$ & $(0.027853)$ \\
\hline \multirow{2}{*}{ ED } & $0.008873^{* *}$ & $0.001873^{* * *}$ & $0.021831^{*}$ & 0.000317 & -0.117308 \\
& $(0.004225)$ & $(0.000416)$ & $(0.011490)$ & $(0.053210)$ & $(0.213370)$ \\
\hline \multirow{2}{*}{ ED2 } & $-0.000555^{* * *}$ & $-0.000078^{* * *}$ & $-0.001455^{*}$ & 0.053827 & 0.053471 \\
& $(0.000273)$ & $(0.000012)$ & $(0.000782)$ & $(0.124073)$ & $(0.214037)$ \\
\hline \multirow{2}{*}{ PUI } & $-0.182041^{* * *}$ & & & & \\
\hline
\end{tabular}


Table 4. Cont.

\begin{tabular}{|c|c|c|c|c|c|}
\hline $\begin{array}{c}\text { Dependent } \\
\text { Variable }\end{array}$ & PRI & PUI & TFP & Interest Rate & Savings \\
\hline (1) & (2) & (3) & (4) & (5) & (6) \\
\hline PRI & & $\begin{array}{c}-0.133082 \text { *** } \\
(0.035968)\end{array}$ & $\begin{array}{c}0.142300 * * \\
(0.055804)\end{array}$ & & \\
\hline TRD & $\begin{array}{l}0.000327 * \\
(0.000170)\end{array}$ & & & $\begin{array}{l}0.015337 * \\
(0.008029)\end{array}$ & \\
\hline INT & $\begin{array}{c}-0.055071 \text { ** } \\
(0.026100)\end{array}$ & $\begin{array}{c}-0.001137 * \\
(0.000605)\end{array}$ & $\begin{array}{c}0.111240 * * * \\
(0.037080)\end{array}$ & & $\begin{array}{c}-0.002152 * * * \\
(0.000749)\end{array}$ \\
\hline GDP & $\begin{array}{c}0.012734^{* * *} \\
(0.003859)\end{array}$ & $\begin{array}{c}0.021514^{* * *} \\
(0.007684)\end{array}$ & $\begin{array}{c}0.015327^{* * *} \\
(0.004142)\end{array}$ & $\begin{array}{c}-0.003017^{* * *} \\
(0.000518)\end{array}$ & $\begin{array}{l}0.032114 * * \\
(0.015514)\end{array}$ \\
\hline POP & & $\begin{array}{c}0.013547 \\
(0.237142)\end{array}$ & $\begin{array}{c}0.000111 \\
(0.023167)\end{array}$ & $\begin{array}{c}0.013072 \\
(0.022377)\end{array}$ & $\begin{array}{c}0.021311^{* * *} \\
(0.003001)\end{array}$ \\
\hline $\begin{array}{l}\text { Threshold of } \\
\text { external debt } \\
\text { servicing }\end{array}$ & $8 \%$ of export & $\begin{array}{c}12.01 \% \text { of } \\
\text { export }\end{array}$ & $\begin{array}{c}7.5 \% \text { of } \\
\text { export }\end{array}$ & - & - \\
\hline $\begin{array}{c}\text { No of } \\
\text { Instruments }\end{array}$ & 28 & 28 & 28 & 28 & 28 \\
\hline $\begin{array}{c}\mathrm{AR}(1): \\
p \text {-value }\end{array}$ & 0.111 & 0.025 & 0.324 & 0.311 & 0.201 \\
\hline $\begin{array}{l}\text { AR(2): } \\
p \text {-value }\end{array}$ & 0.428 & 0.107 & 0.290 & 0.388 & 0.131 \\
\hline $\begin{array}{l}\text { Sargan test: } \\
p \text {-value }\end{array}$ & 0.405 & 0.221 & 0.147 & 0.506 & 0.167 \\
\hline $\begin{array}{c}\text { Hansen test: } \\
p \text {-value }\end{array}$ & 0.312 & 0.342 & 0.428 & 0.274 & 0.214 \\
\hline
\end{tabular}

Notes: All variables are in logarithm form; ${ }^{*},{ }^{* *}$ and ${ }^{* * *}$ represent significance at $10 \%, 5 \%$ and $1 \%$, respectively $Z_{t-1}=$ lagged dependent variable, PRI = private investment, $\mathrm{PUI}=$ public investment, TFP = total factor productivity, $\mathrm{ED}=$ external debt, ED2 = squared external debt, TRD = trade openness, INT = interest rate, GDP = real GDP per capita, POP = population growth; Values in parentheses represent standard errors.

\section{Conclusions}

This study aimed to explore the channels through which external debt transmits its effects on economic growth in SSA countries. To this end, panel data comprising 30 SSA countries from 1985 to 2019 was estimated using the GMM estimation technique. Findings from the study indicated that external debt transmits a non-linear effect to economic growth in SSA countries through the channels of private investment, public investment and total factor productivity. It was also confirmed that interest rate constitutes a channel for transmitting a direct rather than non-linear impact to economic growth. Contrariwise, the estimates showed that savings do not function as a channel of transmission between the two variables. All the results were found to pass the robustness test, except that of the interest rate model. It was found that the interest rate is not a channel for transmitting the effect of external debt servicing to economic growth.

Policy implications arising from this study include the need for SSA countries to pursue external debt reduction strategies to reduce the negative impact on the identified channels. Particularly, as a way of reducing the crowding-out effect of external debt accumulation on investment as implied in the study, SSA countries should endeavor to explore other viable sources of financing their expenditures such as rejigging and deepening of domestically generated revenue, the attraction of foreign aid and debt forgiveness. They could even work towards phasing out the debt instruments in favor of equity instruments (Faria et al. 2007), while also employing the already accumulated debt productively and ensuring their allocation to sectors that would guarantee a higher return on investment. 
Meanwhile, efforts towards reducing the stock of external debt alone would not translate into higher growth if not supported by sound macroeconomic policies. To this end, macroeconomic policies should be oriented towards improving the identified channels. Private investment should be driven by deliberate policies geared towards improving access to funds, provision for enabling an environment for industries to thrive in and attracting foreign investment to counteract the negative impact of high external debt and that of the crowding-out effect of public debt. To improve TFP, increased attention and funding should be provided for science, mathematics, technology and engineering education. Simultaneously, academic exchange programs in those fields should be facilitated with institutions in industrialized countries. Production efficiency should be driven through investment in human capital development, massive acquisition of productive equipment and international best-practice corporate governance and managerial processes to move the economies' production possibility frontier outward and enhance their industrial potential. Monetary authorities could also drive private investment by enhancing access to funds by reducing interest rates. Currently, bank lending rates in SSA are some of the highest globally, with Madagascar's lending rate being as high as 55.39\% as of 2019. The rates in most other countries in the region are double-digit (IMF 2019). Lastly, fiscal authorities in SSA countries could prevent or reduce the transmission of negative impact from the identified channels by working towards ensuring that their external debt stocks do not exceed the thresholds as determined in the study: $33.01 \%$ of GDP, $138 \%$ of export and $7.5 \%$ of export for interest payment on external debt.

Author Contributions: Conceptualization, A.H.; methodology, A.H. and D.M.; software, A.H. and D.M.; validation, A.H. and D.M.; formal analysis, A.H.; investigation, A.H. and D.M.; resources, D.M.; data curation, A.H. and D.M.; writing-original draft preparation, A.H.; writing-review and editing, A.H. and D.M.; visualization, A.H. and D.M.; supervision, D.M.; project administration, D.M.; funding acquisition, D.M. Both authors have read and agreed to the published version of the manuscript.

Funding: This research received no external funding.

Conflicts of Interest: The authors declare no conflict of interest.

\section{Appendix A}

Table A1. List of countries.

\begin{tabular}{ccc}
\hline Angola & Ghana & Nigeria \\
\hline Botswana & Guinea & Senegal \\
\hline Burkina Faso & Guinea-Bissau & Sierra-Leone \\
\hline Cameroon & Kenya & South Africa \\
\hline Congo, Democratic Republic & Liberia & Sudan \\
\hline Congo Republic & Madagascar & Tanzania \\
\hline Cote d'Ivoire & Malawi & Togo \\
\hline Ethiopia & Mali & Uganda \\
\hline Gabon & Mozambique & Zambia \\
\hline Gambia & Niger & Zimbabwe
\end{tabular}

\section{References}

Adam, Christopher S., and David L. Bevan. 2005. Fiscal deficits and growth in developing countries. Journal of Public Economics 89: 571-97. [CrossRef]

Ali, Rifaqat, and Usman Mustafa. 2012. External debt accumulation and its impact on economic growth in Pakistan. The Pakistan Development Review 51: 79-96. [CrossRef] 
Amin, Aloysius A., and Isa Audu. 2006. External debt, investment and economic growth: Evidence from Nigeria. CBN Economic and Financial Review 44: 1-20.

Arellano, Manuel, and Stephen Bond. 1991. Some tests of specification for panel data: Monte Carlo evidence and an application to employment equations. Review of Economic Studies 58: 227-97. [CrossRef]

Arellano, Manuel, and Olympia Bover. 1995. Another look at the instrumental variables estimation of error-component model. Journal of Econometrics 68: 29-51. [CrossRef]

Asafo, Shuffield S., Matuka Adeladja, and Dominic Nyendu. 2019. External debt and economic growth: Two-step GMM evidence for sub-Saharan African countries. International Journal of Business, Economics and Management 6: 39-48. [CrossRef]

Avramovich, Dragoslav. 1964. Economic Growth and External Debt. Baltimore: The Johns Hopkins Press.

Bakar, Abu, and Sallahuddin Hassan. 2008. Empirical evaluation on external debt of Malaysia. International Business and Economics Research Journal 7: 95-108. [CrossRef]

Beck, Thorsten, Ross Levine, and Norman Loayza. 2000. Finance and the sources of growth. Journal of Financial Economics 58: 261-300. [CrossRef]

Blavy, Rodolphe. 2006. Public Debt and Productivity: The Difficult Quest for Growth in Jamaica. International Monetary Fund Working Paper 06(235). Washington, DC: International Monetary Fund.

Blundell, Ruichard, and Steven Bond. 1998. Initial conditions and moment restrictions in dynamic panel data models. Journal of Econometrics 87: 115-43. [CrossRef]

Borensztein, Eduardo. 1990. Debt overhang, credit rationing and investment. Journal of Development Economics 32: 315-35. [CrossRef]

Cassimon, Danny, and Joss Vaessen. 2007. Theory, practice and potential of debt for development swaps in the Asian and Pacific region. Economic Systems 31: 12-34. [CrossRef]

Checherita-Westphal, Cristina, and Philipp Rother. 2012. The impact of high government debt on economic growth and its channels: An empirical investigation for the Euro area. European Economic Review 56: 1392-405. [CrossRef]

Ciftcioglu, Serhan, and Amin Sokhanvar. 2018. External debt-economic growth nexus in selected CEE countries. Romanian Journal of Economic Forecasting 21: 85-100.

Claessens, Stijn, and Ishac Diwan. 1990. Investment incentives: New money, debt relief, and the critical role of conditionality in the debt crisis. The World Bank Economic Review 4: 21-41. [CrossRef]

Clements, Michael P., and Hans-Martin Krolzig. 2003. Business cycle asymmetries: Characterisation and testing based on Markovswitching autoregressions. Journal of Business Economics and Statistics 21: 196-211. [CrossRef]

Cohen, Daniel. 1995. Large external debt and (slow) domestic growth: A theoretical analysis. Journal of Economic Dynamics and Control 19: 1141-63. [CrossRef]

Cordella, Tito, Luca Antoni Ricci, and Marta Ruiz-Arranz. 2005. Debt Overhang or Debt Irrelevance? Revisiting the Debt-Growth Link. International Monetary Fund Working Paper [WP/05/22]. Washington, DC: International Monetary Fund.

Deshpande, Ashwini. 1997. The debt overhang and the disincentive to invest. Journal of Development Economics 52: 169-87. [CrossRef]

Dey, Sima R., and Mohammad Tareque. 2019. External debt and growth: Role of stable macroeconomic policies. Journal of Economics, Finannce and Administrative Science. [CrossRef]

Drine, Imed, and Sami M. Nabi. 2010. Public external debt, informality and production efficiency in developing countries. Economic Modelling 27: 487-95. [CrossRef]

Easterly, William. 2002. How did heavily indebted poor countries become heavily indebted? Reviewing two decades of debt relief. World Development 30: 1677-96. [CrossRef]

Edet-Nkpubre, Arit. 2013. Exploring the nexus between external debt management and economic growth. International Journal of Economic Resources 412: 43-65.

Edo, Samson, Nneka E. Osadolor, and Isuwa F. Dading. 2020. Growing external debt and declining export: The concurrent impediments in economic growth of sub-Saharan African countries. International Economics 161: 173-87. [CrossRef]

Elbadawi, Ibrahim, Benno J. Ndulu, and Njuguna Ndung'u. 1997. Debt overhang and economic growth in sub-Saharan Africa. In IMF And World Bank 1997 Conference Paper on External Financing for Low-Income Countries. Washington, DC: International Monetary Fund, pp. 49-76.

Faria, Andre, Paolo Mauro, Philip R. Lane, and Gian M. Milesi-Ferretti. 2007. The shifting composition of external liabilities. Journal of the Eupean Economic Association 5: 480-90. [CrossRef]

Ferrarini, Benno. 2008. Proposal for a contingent debt sustainability framework. World Development 36: 2547-65. [CrossRef]

Gazdar, Kaouthar, and Mondher Cherif. 2015. Institutions and the finance-growth nexus: Empirical evidence from MENA countries. Borsa Istanbul 15: 137-60. [CrossRef]

Gomez-Puig, Marta, and Simon Sosvilla-Rivero. 2017. Heterogeneity in the debt-growth nexus: Evidence from EMU countries. International Review of Economics and Finance 51: 470-86. [CrossRef]

Hassan, Adewale S., Daniel F. Meyer, and Sebastian Kot. 2019. Effect of institutional quality and wealth from oil revenue on economic growth in oil-exporting developing countries. Sustainability 11: 3635. [CrossRef]

IMF. 2019. International Financial Statistics. Washington, DC: International Monetary Fund.

Iyoha, Milton A. 1999. External Debt and Economic Growth in Sub-Saharan African Countries: An Econometric Study. AERC Research Paper 90. Nairobi: African Economic Research Consortium. 
Joshua, Udi, Festus F. Adedoyin, and Samuel A. Sarkodie. 2020. Examining the external-factors-led growth hypothesis for the South African economy. Heliyon 6: 1-8. [CrossRef] [PubMed]

Karagol, Erdal. 2002. The causality analysis of external debt service and GNP: The case of Turkey. Central Bank Review 85: $1106-17$.

Kourtellos, Andros, Thanasis Stengos, and Chih Ming Tan. 2013. The effect of public debt on growth in multiple regimes. Journal of Macroeconomics 38: 35-43. [CrossRef]

Krugman, Paul. 1988. Financing vs. forgiving a debt overhang. Journal of Development Economics 29: 253-68. [CrossRef]

Kumar, Manmohan, and Jaejoon Woo. 2010. Public Debt and Growth. International Monetary Fund Working Paper [WP/10/174]. Washington, DC: International Monetary Fund.

Law, Siong H., Ali M. Kutan, and N. A. M. Naseem. 2018. The role of institutions in finance curse: Evidence from international data. Journal of Comparative Economics 46: 174-91. [CrossRef]

Loser, Claudio M. 2004. External Debt Sustainability: Guidelines for Low- and Middle-Income Countries. Available online: https: / / unctad.org/en/docs/gdsmdpbg2420042_en.pdf/ (accessed on 24 March 2018).

Muhanji, Stella, and Kalu Ojah. 2011. Management and sustainability of external debt: A focus on the emerging economies of Africa. Review of Development Finance 1: 184-206. [CrossRef]

Ndikumana, Leonce, and James K. Boyce. 2011. Capital flight from sub-Saharan Africa: Linkages with external borrowing and policy options. International Review of Applied Economics 25: 149-70. [CrossRef]

Ogunlana, Olarewaju F. 2016. Causal nexus between external debt and economic growth: The Nigerian case. International Journal of Management and Commerce Innovations 4: 92-97.

Olaniyi, Clement O., and Sunday I. Oladeji. 2020. Moderating the effect of institutional quality on the finance-growth nexus: Insights from West African countries. Economic Change and Restructuring. [CrossRef]

Ouedraogo, Jerome. 2015. External Debt, Quality of Institutions and Economic Growth in WAEMU. In Regional Integration and Policy Challenges in Africa. Edited by A. B. Elhiraika, A. C. K. Mukungu and W. Nyoike. London: Palgrave Macmillan, pp. $124-42$.

Panizza, Ugo, and Andrea F. Presbitero. 2014. Public debt and economic growth: Is there a causal effect? Journal of Macroeconomic 2699: 1-41. [CrossRef]

Pattillo, Catherine, Helen Poirson, and Luca Ricci. 2002. External debt and growth. Finance and Development 39: 1-15. [CrossRef]

Pattillo, Catherine, Helen Poirson, and Luca Ricci. 2004. What Are the Channels through Which External Debt Affects Growth? International Monetary Fund Working Paper [WP/04/15]. Washington, DC: International Monetary Fund.

Pattillo, Catherine, Helen Poirson, and Luca Ricci. 2011. External debt and growth. Review of Economics and Institutions 2: 1-30. [CrossRef]

Pescatori, Andrea, Damiano Sandrin, and John Simon. 2014. Debt and Growth: Is There a Magic Threshold? International Monetary Fund Working Paper [WP/14/34]. Washington, DC: International Monetary Fund.

Qureshi, Irfan, and Zara Liaqat. 2020. The long-term consequences of external debt: Revisiting the evidence and inspecting the mechanism using panel VARs. Journal of Macroeconomics 63: 1-19. [CrossRef]

Riffat, Nisma, and Kashif Munir. 2015. Exploring the Channels and Impact of Debt on Economic Growth in South Asia. MPRA Paper No. 66830. Available online: https:/ / mpra.ub.uni-muenchen.de/66830/ (accessed on 23 April 2018).

Roodman, David. 2009. How to do xtabond2: An introduction to difference and system GMM in Stata. The Stata Journal 9: 86-136. [CrossRef]

Sachs, Jeffrey. 1989. The Debt Overhang of Developing Countries. In Debt, Stabilisation and Development. Edited by G. A. Calvo, J. K. Pentti and J. B. Macedo. Oxford: Blackwell.

Schclarek, Alfredo. 2004. Debt and Economic Growth in Developing and Industrial Countries. Available online: http://www.nek.lu. se/publications/workpap/Papers/WP05_34.pdf (accessed on 22 May 2018).

Schclarek, Alfredo, and Francisco Ramon-Ballester. 2005. External Debt and Economic Growth in Latin America. Available online: http: / / www.cbaeconomia.com/Debt-latin.pdf (accessed on 15 July 2018).

Senadza, Bernardin, Agbemavor Fiagbe, and Peter Quartey. 2018. The effect of external debt on economic growth in sub-Saharan Africa. International Journal of Business and Economic Sciences Applied Research 11: 61-69.

Silva, Jorge. 2020. Impact of public and private sector external debt on economic growth: The case of Portugal. Eurasian Economic Review 10: 607-34. [CrossRef]

Soydan, Aylin, and Serap Bedir. 2015. External debt and economic growth: New evidence for an old debate. Journal of Business, Economics and Finance 4: 500-22. [CrossRef]

Were, M. 2001. The Impact of External Debt on Economic Growth in Kenya: An Empirical Assessment. WIDER Discussion Paper 2001/116. Helsinki: World Institute for Development Economics (UNU-WIDER).

World Bank. 2010. Global Development Finance-External Debt of Developing Countries. Washington, DC: World Bank.

World Bank. 2017. International Debt Statistics. Washington, DC: World Bank.

World Bank. 2020. International Debt Statistics. Washington, DC: World Bank. 